\title{
Antonina ChŁopecka
}

\author{
Uniwersytet Warszawski
}

\section{PROBLEMATYKA MAJĄTKU UJAWNIONEGO PO ZAKOŃCZENIU POSTĘPOWANIA LIKWIDACYJNEGO SPÓŁKI KAPITAŁOWEJ}

\section{WPROWADZENIE}

Jednym z problemów pojawiającym się w orzecznictwie, a także mającym znaczenie dla bieżącej działalności Krajowego Rejestru Sądowego ${ }^{1}$ jest sytuacja, gdy po wykreśleniu spółki kapitałowej - z ograniczoną odpowiedzialnością bądź akcyjnej z rejestru przedsiębiorców pozostają aktywa należące do likwidowanego majątku takiej - już nieistniejącej spółki. Problem ten nie został przez ustawodawcę rozwiązany w kodeksie spółek handlowych ${ }^{2}$ ani w innych regulacjach ${ }^{3}$. Problematyka ta pojawiała się jednak wielokrotnie w orzecznictwie Sądu Najwyższego, zarówno w okresie obowiązywania kodeksu handlowego z 1934 r. ${ }^{4}$, jak i kodeksu spółek handlowych. Poglądy orzecznictwa na sposób rozwiązania tego problemu zmieniały się w czasie. Analizując orzecznictwo z obecnej perspektywy, należy uznać, że wydaje się ono niespójne, co w konsekwencji powoduje, iż jest krytykowane przez doktrynę. Problem

1 Ustawa z 20 sierpnia 1997 r. o Krajowym Rejestrze Sądowym (tekst jedn. Dz. U. z 2017 r. poz. 700 ze zm.); dalej: ustawa o KRS.

2 Ustawa z 15 września 2000 r. - Kodeks spółek handlowych (tekst jedn. Dz. U. z 2017 r. poz. 1577 ze zm.); dalej: k.s.h.

3 A. Koniewicz, Majątek polikwidacyjny osób prawnych na przykładzie spółek kapitałowych, Warszawa 2010, s. 244 i n.

4 Orzeczenie Sądu Najwyższego z 26 maja 1936 r., II C 331/36. 
wydaje się szczególnie poważny, gdy w skład majątku wchodzi nieruchomość - w polskim systemie prawnym bowiem, odmiennie niż chociażby w prawodawstwie niemieckim, nieruchomość nie może być tzw. rzeczą niczyją ${ }^{5}$. Praktyką przyjętą przez KRS jest ponowne podejmowanie postępowania likwidacyjnego w odniesieniu do takiej spółki, która to praktyka rodzi jednak trzy zasadnicze wątpliwości. Po pierwsze, jeżeli po wykreśleniu z rejestru spółki okaże się, że pozostała po niej część majątku nieobjęta likwidacją, powstaje pytanie, czy w ogóle dopuszczalne jest ustanowienie likwidatora w celu dokończenia likwidacji. Po drugie, powstaje pytanie, czy mimo wykreślenia spółki z KRS-u, gdy ujawni się niezlikwidowany majątek spółki - faktycznie mamy do czynienia z podmiotem już nieistniejącym. Po trzecie, rozważyć należy kwestię, jaką regulację prawną powinno się stosować do ponownego podjęcia postępowania likwidacyjnego (o ile przyjmiemy w ogóle zasadność takiego wznowienia). Rozważona powinna być także kwestia wznawiania postępowania likwidacyjnego przez organ rejestrowy, co w doktrynie bywa postrzegane jako „reaktywacja” spółki bez uwzględnienia woli byłych wspólników (akcjonariuszy).

\section{Poglądy Wyrażone w orzecznictwie SĄDU NaJWyższego}

W odniesieniu do pierwszego postawionego przeze mnie pytania czy dopuszczalne jest ustanowienie likwidatora w celu dokończenia likwidacji, Sąd Najwyższy już w uchwale z 26 kwietnia 1995 r. pośrednio dopuścił taką możliwość 6 . W uchwale z 24 stycznia 2007 r.7 stanął na stanowisku, że dopuszczalne jest ustanowienie likwidatora dla spółki z ograniczoną odpowiedzialnością w celu dokończenia likwidacji. Sąd Najwyższy podkreślił ponadto, że prawa do aktywów stanowiących

5 Co do rozważań dotyczących dopuszczalności funkcjonowania w obrocie nieruchomości „niczyjej” i stwierdzenia, że na gruncie prawa polskiego prawo własności nie może być tzw. prawem bezpodmiotowym, a nieruchomość nie może być nieruchomością „niczyją”, por. A. Koniewicz, op. cit., s. 176 i n.

6 Ibidem, s. 269; por. też uchwała Sądu Najwyższego z 26 kwietnia 1995 r., III CZP 44/95, «OSNC» 9/1995, poz. 123.

7 Uchwała Sądu Najwyższego z 24 stycznia 2007 r., III CZP 143/06, «Lex» nr 209069. 
składnik majątku nieobjętego likwidacją nie przechodzą bezpośrednio na byłych wspólników, jak przyjmowało orzecznictwo w czasie obowiązywania kodeksu handlowego. Uzasadnieniem poglądu wypływającego z wspomnianego wyżej orzeczenia z 2007 r. jest wskazanie, że takie rozwiązanie mogłoby prowadzić do nadużyć i pokrzywdzenia interesów wierzycieli. Sąd Najwyższy uznał, że w braku przepisów, które w takiej sytuacji można zastosować wprost, należy posłużyć się analogią. Sąd Okręgowy, przedstawiający Sądowi Najwyższemu zagadnienie prawne, zaproponował odwołanie się do analogii z art. 184 kodeksu rodzinnego i opiekuńczego ${ }^{8}$ bądź analogii z art. $666 \$ 1$ kodeksu postępowania cywilnego'. Sąd Najwyższy odrzucił obydwa te rozwiązania, tłumacząc, że artykuł kodeksu rodzinnego i opiekuńczego przewidujący ustanowienie kuratora dla osoby nieobecnej nie może być zastosowany do sytuacji, gdy $\mathrm{w}$ sprawie mamy do czynienia $\mathrm{z}$ osobą prawną nieistniejącą. Również zastosowanie w drodze analogii art. $666 \$ 1$ k.p.c. byłoby, zdaniem Sądu Najwyższego, w tym przypadku nieuzasadnione, ponieważ zadaniem kuratora spadku, określonym w art. 667 k.p.c., jest ustalenie tożsamości spadkobierców i zawiadomienie ich o otwarciu spadku. Niemożliwość odpowiedniego zastosowania tego przepisu wynika z faktu, że w sprawie nie ma wątpliwości co do tożsamości osób byłych wspólników spółki ani problemu $\mathrm{z}$ ustaleniem ich adresów. Zastosowanie przepisu z materii prawa spadkowego przeczyłoby ponadto istocie i funkcji analogii, która zakłada nawiązywanie do przepisu pochodzącego z tego samego, a co najmniej z pokrewnego aktu prawnego. Sąd Najwyższy, kończąc rozważania, stwierdził, że w sytuacji, gdy część majątku spółki nie została objęta postępowaniem likwidacyjnym, należy stwierdzić, iż jego zakończenie było przedwczesne i konieczne jest ponowne powołanie likwidatora. Podstawą prawną decyzji sądu rejestrowego powinien być stosowany w drodze analogii art. 170 k.s.h., który dotyczy likwidacji spółki w organizacji. Sąd Najwyższy uzasadnił wskazaną analogiae legis $\mathrm{w}$ ten sposób, że skoro dopuszczalne jest prowadzenie postępowania

8 Ustawa z 25 lutego 1964 r. - Kodeks rodzinny i opiekuńczy (tekst jedn. Dz. U. z 2017 r. poz. 682); dalej: k.r.o.

9 Ustawa z 17 listopada 1964 r. - Kodeks postępowania cywilnego (tekst jedn. Dz. U. z 2018 r. poz. 155 ze zm.); dalej: k.p.c. 
likwidacyjnego wobec spółki w organizacji, która z racji nieuzyskania wpisu w rejestrze nie posiada osobowości prawnej, to możliwe jest również wszczęcie takiego postępowania w celu dokończenia likwidacji majątku spółki zarejestrowanej, wykreślonej już z rejestru w wyniku postępowania likwidacyjnego, lecz w sytuacji pominięcia w postępowaniu części majątku tej spółki.

W postanowieniu Sądu Najwyższego z 19 września 2013 r. ${ }^{10}$ została postawiona teza, że w sytuacji, gdy spółka kapitałowa została wykreślona uprzednio z rejestru przedsiębiorców, jednakże część jej majątku nie została objęta postępowaniem likwidacyjnym - nie można twierdzić, iż ma się do czynienia z podmiotem już nieistniejącym. W związku z tym takiego „podmiotu” może dotyczyć postępowanie o wpis lub jego wykreślenie na podstawie art. $519^{1} \$ 3$ k.p.c. Sąd Najwyższy uznał, że spółka mimo wykreślenia $\mathrm{z}$ rejestru ma zdolność likwidacyjną oraz zdolność sądową w tym zakresie, ponieważ formalne zakończenie postępowania likwidacyjnego było w stosunku do spółki przedwczesne. Przyjął zatem swoistą fikcję „dalej toczącego się postępowania”. Zdaniem Sądu Najwyższego należy w takiej sytuacji wyznaczyć likwidatora oraz dokonać wpisu okoliczności podjęcia postępowania likwidacyjnego do rejestru przedsiębiorców. Podstawą prawną takiego rozwiązania w przypadku spółki akcyjnej powinny być stosowane w drodze analogii przyjęte przepisy kodeksu spółek handlowych o likwidacji spółki w organizacji, czyli odpowiednio przepisy art. $326 \$ 1$ k.s.h.

Również uchwała Sądu Najwyższego z 3 grudnia 2014 r. ${ }^{11}$ dotyczyła problematyki ujawnienia po wykreśleniu spółki akcyjnej z rejestru przedsiębiorców majątku spółki nieobjętego likwidacją. Sąd Najwyższy we wspomnianej uchwale rozważał, które przepisy kodeksu spółek handlowych w drodze analogii powinny być stosowane w omawianej sytuacji. Odniesiono się także do koncepcji wykreślenia z rejestru przedsiębiorców wpisu o wykreśleniu spółki handlowej na podstawie art. 12

10 Postanowienie Sądu Najwyższego z 19 września 2013 r., I CZ 69/13, «Lex» nr 1378525.

11 Uchwała Sądu Najwyższego z 3 grudnia 2014 r., III CZP 90/14, «Lex» nr 1574378. 
ust. 3 ustawy o KRS ${ }^{12}$. Wedle tej koncepcji, w sytuacji gdy w rejestrze umieszczone są dane niezgodne $\mathrm{z}$ obowiązującymi przepisami prawa, sąd rejestrowy, po wysłuchaniu zainteresowanych osób na posiedzeniu lub po wezwaniu do złożenia oświadczenia na piśmie, wykreśla je $\mathrm{z}$ urzędu. W tej sytuacji wpisem niedopuszczalnym byłby wpis o wykreśleniu spółki, jeśli następnie ujawni się majątek nieobjęty likwidacją. Postępowanie likwidacyjne, które nie obejmowałoby całego majątku spółki kapitałowej, byłoby bowiem postępowaniem niezgodnym z prawem. Sąd Najwyższy odniósł się krytycznie do tej koncepcji. Po pierwsze, wskazał, że naruszona zostałaby zasada niewzruszalności wpisu oraz zasada niewzruszalności prawomocnych orzeczeń sądowych stanowiących podstawę dokonania wpisów w rejestrze. Po drugie, przeczyłoby to konstytutywnemu charakterowi wpisu o wykreśleniu spółki handlowej z rejestru przedsiębiorców. Sytuacja swoistej „reaktywacji” spółki handlowej wpływałaby również negatywnie na pewność oraz bezpieczeństwo obrotu prawnego. Wykreślenie osoby prawnej z rejestru powinno definitywnie kończyć jej istnienie. Sąd Najwyższy postawił również omawianej koncepcji zarzut naruszenia konstrukcji spółki handlowej, będącej podmiotem o charakterze korporacyjnym. Kres istnienia spółki z ograniczoną odpowiedzialnością (akcyjnej) powoduje doniosłe skutki także dla wspólników (akcjonariuszy) w postaci wygaśnięcia więzi korporacyjnej (poprzez ustanie bytu prawnego udziałów bądź akcji) między osobami wspólników (akcjonariuszy) a spółką. Niedopuszczalne więc byłoby przyw rócenie członkostwa w spółce w drodze wznowienia postępowania upadłościowego. Wynika to w szczególności z faktu, że nawiązanie stosunku członkostwa następuje w drodze umowy pomiędzy wspólnikiem (akcjonariuszem) a spółką. Sąd Najwyższy w omawianej uchwale stanął więc na stanowisku, które zostało wyrażone wcześniej w uchwale Sądu Najwyższego z 24 stycznia 2007 r. (III CZP 143/06), mówiącym, że w razie ujawnienia po wykreśleniu spółki akcyjnej z rejestru przedsiębiorców majątku spółki nieobjętego likwidacją, stosuje

12 S. Babiarz, W. Łukowski, Glosa do uchwały SN z dnia 24 stycznia 2007 r., III CZP 143/06, «Prawo Spółek» 3/2010, s. 52 i n. 
się w drodze analogii przepisy kodeksu spółek handlowych dotyczące likwidacji spółki akcyjnej w organizacji.

Warto zwrócić uwagę także na wyrok Sądu Najwyższego z 13 grudnia 2006 r. ${ }^{13}$ Sprawa rozstrzygana przez Sąd Najwyższy dotyczyła byłych członków zarządu spółki, którzy zostali pozwani już po przeprowadzeniu postępowania likwidacyjnego wobec spółki. Sąd Najwyższy podniósł, że w sytuacji, w której spółka utraciła osobowość prawną poprzez wykreślenie jej z rejestru i przestała istnieć w obrocie prawnym, należy uznać, iż w tym szczególnym przypadku możliwe jest usprawiedliwienie wyjątku od zasady, zgodnie z którą wierzyciel powołujący się na bezskuteczność egzekucji przeciwko spółce z ograniczoną odpowiedzialnością nie może pozwać członka zarządu tej spółki na podstawie art. 299 k.s.h., o ile wcześniej nie uzyska tytułu egzekucyjnego przeciwko spółce. W sytuacji wcześniejszej likwidacji spółki uzyskanie bowiem tytułu wykonawczego przeciwko podmiotowi już nieistniejącemu byłoby niewykonalne. Ta szczególna okoliczność uzasadniała więc, zdaniem Sądu Najwyższego, możliwość wszczęcia postępowania przeciwko byłym członkom zarządu. Sąd Najwyższy dopuścił taką interpretację ze względu na potrzebę ochrony wierzycieli nieistniejącej już spółki. Orzeczenie to, mimo że zostało wydane przeciwko byłym członkom zarządu, przemawia za dopuszczalnością wznowienia postępowania likwidacyjnego wobec spółki już nieistniejącej, skoro istnieje majątek, należący do spółki, który został ujawniony już po formalnym zakończeniu postępowania likwidacyjnego.

\section{PRZEGLĄD OPINII DOKTRYNY}

Analiza obowiązującego stanu prawnego na podstawie powołanego orzecznictwa świadczy bezspornie o tym, że mamy do czynienia z luką w prawie. Sąd Najwyższy starał się w orzecznictwie zaproponować rozwiązanie omawianego przeze mnie problemu, jednak w mojej ocenie, ze względu na niekompletność ustawodawstwa, odniesienia do obowiązujących przepisów nie usuwają niespójności istniejącej regulacji (a raczej jej braku). Jak już wskazałam, Sąd Najwyższy reprezentuje pogląd, że

13 Wyrok Sądu Najwyższego z 13 grudnia 2006 r., II CSK 300/06, «Lex» nr 388845. 
najodpowiedniejsze w sytuacji pozostania majątku spółki handlowej wykreślonej z rejestru przedsiębiorców, nieobjętego likwidacją, jest stosowanie w drodze analogii art. 170 k.s.h. w odniesieniu do spółki z ograniczoną odpowiedzialnością oraz art. $326 \$ 1$ k.s.h. w odniesieniu do spółki akcyjnej. Warto jednak odnieść się do stanowisk glosatorów uchwały z 24 stycznia 2007 r. Zostało podniesione ${ }^{14}$, że brakuje podobieństwa między sytuacją likwidacji spółki w organizacji a podjęciem postępowania likwidacyjnego w razie ujawnienia się składników majątku spółki, które likwidacją nie zostały objęte. Po pierwsze, art. 170 k.s.h. dotyczy podmiotu (a w zasadzie tzw. ułomnej osoby prawnej), jakim jest niewątpliwie spółka w organizacji. W przypadku nieobjęcia części majątku postępowaniem likwidacyjnym mamy natomiast do czynienia z masą majątkową, która z racji wykreślenia spółki z rejestru przedsiębiorców nie ma właściciela - nawet „w postaci” owej ułomnej osoby prawnej ${ }^{15}$. Sytuacja ujawnienia majątku spółki, po zakończeniu postępowania likwidacyjnego, różni się diametralnie od sytuacji likwidacji spółki w organizacji. Należy pamiętać, że spółce w organizacji na mocy przepisu art. 17 k.s.h. została przyznana zdolność prawna. Wedle bowiem ogólnego przepisu art. $33^{1}$ kodeksu cywilnego ${ }^{16}$ niezbędna jest wyraźna podstawa ustawowa dla przyznania podmiotowi, który nie jest osobą prawną, zdolności prawnej. W przypadku spółki wykreślonej z rejestru nie możemy mówić o istnieniu podstawy prawnej dla przyznania jej zdolności sądowej, a więc i likwidacyjnej. W doktrynie ten argument bywa podnoszony w celu zakwestionowania rzekomo podobnej natury spółki w organizacji i spółki wykreślonej z rejestru ${ }^{17}$. Przede wszystkim jednak spółka wykreślona z rejestru przedsiębiorców definitywnie zakończyła swój byt. Po stronie wspólników (akcjonariuszy)

14 A. Koniewicz, Glosa do uchwały SN z dnia 24 stycznia 2007 r., III CZP 143/06, «Glosa» 4/2010, s. 40 i n.

15 A. Wowerka, Glosa do uchwały SN z dnia 24 stycznia 2007 r., III CZP 143/06, «Gdańskie Studia Prawnicze - Przegląd Orzecznictwa» 3/2008, s. 57 i n.; A. JAKUBECKI, Glosa do uchwały SN z dnia 24 stycznia 2007 r., III CZP 143/06, «OSP» 7/2008, s. 74 i n.

16 Ustawa z 23 kwietnia 1964 r. - Kodeks cywilny (tekst jedn. Dz.U. z 2017 r. poz. 459 ze zm.).

17 R. Kos, M. Porzycki, op. cit., s. 25. 
nie ma bowiem woli dalszego uczestnictwa w spółce. Inaczej wygląda kwestia niezgłoszenia do sądu rejestrowego spółki już zawiązanej. Wolę istnienia spółki wyraża po stronie wspólników (akcjonariuszy) zawarta umowa spółki. Kwestią wtórną jest jednak fakt, że z różnych względów spółka ta mogła nie zostać zgłoszona do rejestru, przez co konieczne jest przeprowadzenie likwidacji.

W doktrynie pojawiają się propozycje, by majątek spółki, ujawniony po zakończeniu postępowania likwidacyjnego, należał ex lege do wspólników. Jest to pogląd, który reprezentowany był już za rządów kodeksu handlowego. Próbą uzasadnienia go jest argument o konieczności wskazania właściciela majątku, bowiem nie możemy mieć do czynienia z majątkiem (w szczególności z nieruchomością) o nieustalonym statusie prawnym. Wspólnicy (akcjonariusze) nabyliby bowiem ten majątek w sposób oczywisty po zakończeniu procesu likwidacyjnego (o ile oczywiście nie zostałby on wcześniej użyty w celu zaspokojenia wierzycieli spółki) ${ }^{18}$.

Innym poglądem występującym w doktrynie jest wskazanie konieczności (lub tylko możliwości) wznowienia postępowania w sprawie wykreślenia osoby prawnej z rejestru. Reprezentanci tego poglądu uzasadniają to stanowisko w ten sposób, że mamy do czynienia z niezgodnym z prawem wykreśleniem spółki z rejestru, bowiem przeprowadzenie postępowania likwidacyjnego jest obligatoryjne. Podstawą prawną wykreślenia spółki z rejestru jest art. 12 ust. 2 lub 3 ustawy o KRS ${ }^{19}$.

\section{Ocena stanu prawnego (DE Lege lata)}

Jeżeli chodzi o ujawniony po formalnym zakończeniu postępowania likwidacyjnego majątek spółki, możemy odróżnić tutaj dwie sytuacje. Pierwsza to ta, gdy w wyniku „niepełnego” postępowania likwidacyjnego pozostaje składnik mienia spółki w postaci ruchomości lub prawa, a druga - gdy składnik mienia stanowi nieruchomość. W pierwszej sytuacji kwestia sytuacji prawnej ujawnionego składnika majątku jest

18 J. Gry kiel, Postępowanie dotyczace aktywów spółki po jej likwidacji. Glosa do uchwaty SN z 24.01.2007 r., III CZP 143/06, «Glosa» 2/2011, s. 17-21.

19 J.P. NAwORsKi, Kodeks spółek handlowych. Komentarz, red. T. SiemiąTKOWSKI, R. Potrzeszcz, Warszawa 2011, s. 596 i n. 
prostsza i nie narusza w sposób bezpośredni pewności obrotu. Chodzi o to, by z ujawnionego majątku zaspokoić niezaspokojone dotąd interesy wierzycieli, a ewentualną nadwyżkę rozdzielić pomiędzy byłych wspólników (akcjonariuszy). Sytuacja komplikuje się jednak, gdy składnikiem majątku jest nieruchomość. W prawie polskim nieruchomość bowiem nie może pozostawać bez właściciela - pojawia się więc pytanie, czyją własność stanowi owa pozostała nieruchomość. Przyjęcie bowiem, że składnik ten stanowi majątek nieistniejącej już spółki, prowadzi do poważnej sprzeczności logicznej. Dana rzecz nie może bowiem być własnością podmiotu, który już nie istnieje. W obecnie obowiązującym stanie prawnym nie doszło do precyzyjnego określenia, czyją własnością jest majątek ujawniony po zakończeniu procesu likwidacji. Nie wynika to ani z przepisów prawa, ani z powołanego przeze mnie orzecznictwa. Sąd Najwyższy, zajmując się proceduralną stroną problemu, nie pochylił się w żaden sposób nad problemem prawa własności. Rodzi to problemy nie tylko natury teoretycznoprawnej, lecz także praktycznej. Przykładowo nie wiadomo bowiem, kto powinien odprowadzać daniny publicznoprawne za nieruchomość.

Nie można przyjąć poglądu, że spółka mimo przeprowadzenia postępowania likwidacyjnego i wykreślenia jej z rejestru nadal istnieje, ponieważ likwidacją nie objęto części jej majątku. Sąd Najwyższy nie dopuścił takiego poglądu, który obecny jest w doktrynie niemieckiej. Według tzw. Doppeltatbestand osoba prawna istnieje dopóty, dopóki widnieje ona w rejestrze i istnieje jej majątek ${ }^{20}$. W prawie polskim stanowisko, że spółka handlowa istnieje tak długo, jak istnieje jej majątek ${ }^{21}$, przeczyłoby istocie konstytutywnego charakteru wpisu do rejestru, który kształtuje stan prawny w tym przypadku w ten sposób, że usuwa niejako spółkę z obrotu i powoduje, iż przestaje ona istnieć. Można próbować bronić stanowiska Sądu Najwyższego, przyjmując, że wznowienie postępowania likwidacyjnego powoduje uchylenie wcześniejszej likwidacji przez uznanie utraty bytu osoby prawnej za niezaistniała. W takiej sytuacji

20 K. Schмidt, Gesellschaftsrecht, Köln-Berlin-Bonn-München 2002, s. 316 i n.

21 R. Potrzeszcz, Wykreślenie spółki kapitałowej bez (właściwej) likwidacji-ze stanowiska wierzycieli, «Rejent» 8.5/1998, s. 152. 
mielibyśmy do czynienia ze skutkiem wstecznym. Przy takim ujęciu nie powstawałby problem, że sąd samodzielnie kreuje osobę prawną, gdyż jedynie stwierdzałby, że ona nadal istnieje, ponieważ jej byt nigdy się nie zakończył. Zatem wznowienie nie miałoby - w odniesieniu do skutków materialnoprawnych - charakteru konstytutywnego, lecz charakter deklaratoryjny. Sąd przyjmowałby, że spółka nadal istnieje, a likwidacja wobec takiej spółki byłaby kontynuowana. Wykreślenie zostałoby w takiej sytuacji uznane przez sąd za błędne i niewywołujące skutków prawnych. Rozwiązanie takie stawiałoby jednak w niekorzystnej sytuacji byłych wspólników (akcjonariuszy), których przez wykreślenie spółki z rejestru przedsiębiorców przestała łączyć więź korporacyjna ze spółką, a zatem przestały na nich spoczywać obowiązki wynikające z posiadania uprawnień korporacyjnych. Stanowiłoby to naruszenie zasady pewności obrotu, gdyby po bliżej nieokreślonym czasie dowiadywali się oni, że mimo wykreślenia spółki z rejestru nadal są oni wspólnikami (akcjonariuszami). Takie rozwiązanie, mimo tego, że z punktu teoretycznoprawnego byłoby spójne i logiczne, to w sposób niedopuszczalny kształtowałoby niekorzystnie sytuację byłych wspólników i akcjonariuszy. Należy pamiętać, że ujawnienie majątku pozostałego po likwidacji może nastąpić nawet po bardzo długim czasie. „Reaktywacja” spółki związana jest z „reaktywacją” wielu obowiązków cywilnoprawnych i publicznoprawnych (sprawozdawczość, podatki etc.), które mogą wpłynąć potencjalnie (i wstecznie) na bilans likwidacyjny nie tylko likwidowanej spółki, ale i jej wspólników (akcjonariuszy). Jedynie tytułem przykładu kilka krótkich pytań: czy akcjonariusz (wspólnik) reaktywowanej spółki ma ująć wstecznie (za ile lat wstecz i po jakiej wartości?) „odtworzone akcje lub udziały? Czy ma może utworzyć rezerwy lub w ogóle skorygować w całości uzyskaną sumę likwidacyjną? Krytykując to podejście, należy stwierdzić, że przyjęcie zasady konstytutywności wpisu jest rozwiązaniem najbardziej racjonalnym, pozwalającym chronić interesy byłych wspólników (akcjonariuszy). Rozwiązanie przeciwne potęguje zaś chaos i stan niepewności prawnej, które są wprawdzie wynikiem nieprawidłowości postępowania likwidacyjnego - nieprawidłowości, która jednak niekoniecznie poprzez zwiększanie chaosu musi być eliminowana z obrotu. Przyjęcie poglądu 
o konieczności „reaktywowania” spółki prowadzi jednak do punktu wyjścia, że sąd, wznawiając postępowanie likwidacyjne, w sposób nieuprawniony ingeruje w stosunek spółki. Dodatkowo należy wskazać, że takie „odtwarzanie” bytu prawnego spółki jest w sensie aksjologicznym (potencjalnie) zasadne tylko wtedy, gdyby istnieli niezaspokojeni wierzyciele likwidowanej spółki, co przecież nie zawsze ma miejsce. Nawet zaś gdyby tacy istnieli, to de lege lata można zastosować interpretację prawa prowadzącą do możliwości ich zaspokojenia z pozostałego majątku, bez „odtwarzania” spółki. Chociaż być może to ostatnie wymaga podniesienia postulatów de lege ferenda. Jak wskazał Sąd Najwyższy, do zawiązania stosunku spółki, a zatem i więzi korporacyjnej pomiędzy wspólnikami (akcjonariuszami) a spółką, niezbędne jest zawarcie przez wspólników (akcjonariuszy) umowy spółki. „Reaktywowanie” spółki handlowej decyzją organu sądowego jest naruszeniem tej zasady. W takiej sytuacji to organ państwowy ingeruje w istnienie więzi korporacyjnej pomiędzy spółką a byłymi wspólnikami (akcjonariuszami), mimo konstytutywnego wpisu o wykreśleniu spółki z rejestru, powodującego ustanie osoby prawnej. Ponadto ustanawianie likwidatora, przy założeniu, że spółka nie istnieje, rodziłoby kolejne problemy. Likwidator, zgodnie z podstawowymi zasadami likwidacji osób prawnych, działa w imieniu tej właśnie osoby. Przy przyjęciu założenia, że osoba prawna nie istnieje, problematyczna byłaby kwestia, w czyim imieniu likwidator właściwie działa. Likwidator w takiej sytuacji musiałby działać albo w imieniu własnym, albo „w imieniu” masy majątkowej, która nie ma właściciela. Przyjęcie takiego poglądu przeczyłoby zasadniczym założeniom likwidacji22.

Stanowisko prezentowane w powołanych orzeczeniach Sądu Najwyższego jest więc w mojej ocenie niespójne. Z jednej strony Sąd Najwyższy broni poglądu o konstytutywnym charakterze wpisu do rejestru i odrzuca koncepcję wykreślenia z rejestru przedsiębiorców wpisu o wykreśleniu spółki handlowej na podstawie art. 12 ust. 3 ustawy o KRS;

22 R. Kos, M. Porzycki, Sytuacja prawna majątku pozostałego po wykreśleniu spółki kapitałowej-uwagi na gruncie postulatu przymusowej likwidacji niewypłacalnych spółek, «Monitor Prawa Handlowego» 3/2013, s. 23. 
z drugiej wskazuje, że w sytuacji, gdy spółka kapitałowa została wykreślona uprzednio z rejestru przedsiębiorców, jednakże część jej majątku nie została objęta postępowaniem likwidacyjnym - nie można twierdzić, iż ma się do czynienia z podmiotem już nieistniejącym, natomiast należy uznać, że postępowanie likwidacyjne nie zostało formalnie zakończone, w związku z czym można je wznowić decyzją organu sądowego. W zasadzie brak jest za to w orzecznictwie koherentnego ujęcia problemu zakresu ochrony wierzycieli nieistniejącej spółki. Po omówieniu tego problemu, omówię też kwestię dopuszczalności ingerencji organu władzy publicznej w kreowanie stosunku spółki poprzez wznawianie postępowania likwidacyjnego, a także przedstawię zagadnienie regulacji dotyczącej ksiąg wieczystych.

5. POGLĄD PIERWSZY - ZBYT SZEROKA OCHRONA WIERZYCIELI NIEISTNIEJĄCEJ JUŻ SPÓŁKI PRZYJĘTA W ORZECZNICTWIE SĄDU NAJWYŻSZEGo

Aktualne orzecznictwo Sądu Najwyższego, odrzucając koncepcję, iżby majątek ujawniony po zakończeniu likwidacji mógł przypadać byłym wspólnikom (akcjonariuszom), daje wyraz szczególnej ochronie wierzycieli. Ochrona wierzycieli wysuwa się na pierwszy plan, marginalizując zasadę pewności obrotu, bowiem mimo zastosowania per analogiam przepisów art. 170 k.s.h. w odniesieniu do spółki z ograniczoną odpowiedzialnością i art. $326 \$ 1$ k.s.h. w odniesieniu do spółki akcyjnej, przed wznowieniem postępowania niewyjaśniony pozostaje status prawny rzeczy należących uprzednio do spółki. Jak już wskazałam, o ile nie jest to aż tak poważny problem praktyczny w przypadku rzeczy ruchomych, o tyle brak określenia statusu nieruchomości wprowadza stan niepewności w obrocie prawnym. Nietrafne wydaje się rozumowanie Sądu Najwyższego, które nakazuje przyznać wierzycielom szczególną ochronę, natomiast odmawia racji bytu koncepcji, wedle której ujawniony majątek należałby do wspólników. Warto zauważyć, że kodeks spółek handlowych już na etapie postępowania likwidacyjnego zapewnia wierzycielom szeroką ochronę. Artykuł 465 k.s.h. reguluje kwestie ogłoszenia o likwidacji i wezwania wierzycieli w przypadku spółki akcyjnej. Powołani likwidatorzy powinni ogłosić dwukrotnie 
o rozwiązaniu spółki i otwarciu likwidacji, wzywając wierzycieli do zgłoszenia ich wierzytelności w terminie sześciu miesięcy od dnia ostatniego ogłoszenia. Ogłoszenia te nie mogą być dokonywane w odstępie czasu dłuższym niż miesiąc ani krótszym niż dwa tygodnie. W trakcie przeprowadzania likwidacji spółki niedozwolona jest wypłata zysków przed uprzednim spłaceniem wszystkich zobowiązań. Zakaz wypłaty zysku dotyczy zarówno zysków, które zostały osiągnięte w trakcie trwania likwidacji, jak i zysków powstałych w okresie działalności spółki, zanim likwidacja została otwarta. Pod pojęciem zysku kryją się również środki zgromadzone przez spółkę na dodatkowych funduszach utworzonych na podstawie umowy spółki, a także uchwał zgromadzenia wspólników (mowa tu przykładowo o utworzonym funduszu inwestycyjnym). Zakaz wypłaty zysków przed zaspokojeniem wszystkich wierzycieli wynika z prawa bezwzględnie obowiązującego i nie można go uchylić umową bądź uchwałą spółki, ponieważ prowadziłoby to do naruszenia interesów wierzycieli spółki²3. W odniesieniu do spółki akcyjnej regulacja art. 474 $\$ 1$ k.s.h. stanowi, że podział między akcjonariuszy majątku pozostałego po zaspokojeniu lub zabezpieczeniu wierzycieli nie może nastąpić przed upływem roku od dnia ostatniego ogłoszenia o otwarciu likwidacji i wezwaniu wierzycieli. Ustawodawca chroni wierzycieli w ten sposób, że pozostawia się wierzycielom dostateczny czas dla zapoznania się z wezwaniem dokonywanym przez spółkę. Odebranie przez akcjonariuszy należności przypadających na akcje przed upływem roku od ostatniego ogłoszenia o likwidacji powoduje po ich stronie powstanie obowiązku do zwrotu, co ma na celu ochronę spóźnionych wierzycieli mających prawo zażądać przysługujących im należności ${ }^{24}$. Z kolei, wedle art. 287 k.s.h. wierzyciele spółki z ograniczoną odpowiedzialnością, którzy nie zgłosili swoich roszczeń we właściwym terminie ani nie byli spółce znani, mogą żądać zaspokojenia swoich należności z majątku spółki jeszcze niepodzielonego. Chronieni są natomiast wspólnicy działający w dobrej wierze, którzy po upływie sześciu miesięcy od daty ogłoszenia

23 Ł. WolbaCh, Likwidacja spółki kapitałowej. Prawo, podatki, rachunkowość, red. W. Missala, Warszawa 2012, s. 184 i n.

24 M. Michalski, Spółka akcyjna, red. A. KidybA, Warszawa 2014, s. 88 i n. 
o otwarciu likwidacji i wezwaniu wierzycieli otrzymali przypadającą na nich część majątku spółki; nie są obowiązani do jej zwrotu w celu pokrycia należności wierzycieli. Artykuł 475 k.s.h. zapewnia także ochronę spóźnionych wierzycieli spółki akcyjnej. Mianowicie, wierzyciele spółki, którzy nie zgłosili swoich roszczeń we właściwym terminie ani nie byli spółce znani, mogą żądać zaspokojenia swoich należności z majątku spółki jeszcze niepodzielonego. Natomiast w $\$ 2$ omawianego artykułu zapewniona jest ochrona akcjonariuszy działających w dobrej wierze. Akcjonariusze, którzy po upływie terminu właściwego do zgłoszenia roszczeń przez spóźnionych wierzycieli otrzymali w dobrej wierze przypadającą na nich część majątku spółki, nie są zobowiązani do jej zwrotu celem pokrycia należności wierzycieli.

Jak widać na podstawie omówionych przepisów, ochrona wierzycieli spółki jest wystarczająco szeroka. Wierzyciele mają moim zdaniem wystarczającą ilość czasu na zgłoszenie swych roszczeń. Rozwiązaniem pozwalającym uczynić zadość obecnej niejasnej sytuacji prawnej ujawnionego majątku byłoby założenie, że majątek ujawniony już po zakończeniu postępowania likwidacyjnego przypadałby byłym wspólnikom (akcjonariuszom). Rozwiązanie takie przewidywało orzecznictwo Sądu Najwyższego za rządów kodeksu handlowego ${ }^{25}$. Regulacja taka byłaby bez wątpienia trafna i nie budziłaby wątpliwości aksjologicznych w sytuacji, gdy w toku postępowania likwidacyjnego interesy wszystkich ujawnionych wierzycieli byłyby zaspokojone. W sytuacji braku niezaspokojonych wierzycieli koncepcja „restytucji” spółki i ponownego prowadzenia postępowania likwidacyjnego (z konsekwencjami w postaci ponownego nawiązywania relacji kontraktowych między spółką a udziałowcami etc.) jest, najdelikatniej mówiąc, naruszeniem tzw. zasady brzytwy Ockhama (czyli tworzeniem bytów ponad konieczność). W innym wypadku, czyli istnienia niezaspokojonych wierzycieli, należałoby rozważyć inne rozwiązanie prowadzące do uwzględnienia interesów tych wierzycieli. Rozwiązanie takie powinno zapewniać spójność regulacji dotyczących postępowania likwidacyjnego i nie prowadzić

25 Orzeczenie Sądu Najwyższego z 26 maja 1936 r., C II 331/36, Zb. Urz. 1/1937, poz. 39. 
do sytuacji, gdy w obrocie istnieją nieruchomości (a i co bardziej wartościowe ruchomości), co do których nie można przypisać właściciela ${ }^{26}$. Odrębnym problemem jest natomiast dopuszczalność takiego rozwiązania na gruncie ustawodawstwa dotyczącego ksiąg wieczystych. Kwestia ta zostanie omówiona później.

Zbyt daleko idąca ochrona wierzycieli wynika także z porównania orzeczeń dotyczących wznowienia likwidacji po ujawnieniu majątku z orzeczeniem Sądu Najwyższego z 13 grudnia 2006 r., w którym uznano za dopuszczalne pozwanie byłych członków zarządu spółki, już po przeprowadzeniu postępowania likwidacyjnego wobec spółki. Między innymi w uchwale Sądu Najwyższego z 24 stycznia 2007 r. Sąd Najwyższy kategorycznie odrzuca koncepcję przejścia ex lege majątku spółki na rzecz jej byłych wspólników, nawet jeżeli wszyscy ujawnieni w postępowaniu likwidacyjnym wierzyciele zostali zaspokojeni (Sąd Najwyższy nie stara się nawet odróżnić sytuacji, gdy ujawnieni wierzyciele zostali zaspokojeni, od sytuacji, gdy do tego zaspokojenia nie doszło). Z drugiej strony Sąd Najwyższy rozszerza w drodze wyjątku odpowiedzialność byłych członków zarządu, co zostało opisane już wcześniej.

Jak sygnalizowałam, inne rozwiązanie należałoby przyjąć, gdyby jeszcze w toku postępowania likwidacyjnego, które zostało formalnie zakonczone, ujawniliby się wierzyciele spółki, których roszczenia - ze względu na niedostateczny majątek spółki - nie zostały zaspokojone. Wówczas przyjęcie rozwiązania, że majątek ujawniony po zakończeniu likwidacji przypadałby ex lege byłym wspólnikom (akcjonariuszom), mogłoby naruszać słuszne interesy tych wierzycieli. W takiej sytuacji, ale też tylko w takiej, w mojej ocenie, słusznym rozwiązaniem byłoby wprowadzenie przez ustawodawcę postępowania, które miałoby charakter quasi-likwidacyjny. Wznowienie postępowania likwidacyjnego, które zostało już

26 Za rozwiązaniem polegającym na sukcesji wspólników (akcjonariuszy) „ujawnionego majątku spółki wykreślonej z rejestru przedsiębiorców opowiada się Antoni Witosz. Twierdzi on, iż takie rozwiązanie nie powinno budzić wątpliwości systemowych. Argumentem przytoczonym przez A. Witosza jest fakt, że byli wspólnicy (akcjonariusze) są nie tylko dawcami kapitału dla spółki, lecz także mają prawo do dywidendy likwidacyjnej. Po drugie, za zasadnością proponowanej regulacji przemawia także praktyka"; por. też A. Witosz, Rozwiązanie i likwidacja spółek handlowych, Warszawa 2014, s. 183 i n. 
formalnie zakończone, nie powinno wchodzić w grę ze względu na to, że organ rejestrowy nie powinien ingerować w wolę wspólników (akcjonariuszy) co do istnienia spółki. Czym in nym jest bowiem zastosowanie analogii z ustawy lub analogii z prawa prowadzące do zastosowania określonych norm prawa materialnego prowadzące do oceny istniejącego stosunku prawnego, a czym innym takie zastosowanie analogii, które kreuje ( odtwarza”) wygasłe stosunki prawne. Tak daleko posunięte stosowanie analogii zdaje się nie mieścić w ramach systemu prawnego, w którym jednym $\mathrm{z}$ dominujących pojęć prawa cywilnego jest jednak autonomia woli stron. W postępowaniu quasi-likwidacyjnym należałoby natomiast rozważyć, kto powoływałby pełnomocnika do spraw likwidacji. Możliwe są tu trzy warianty. W pierwszym z nich zaspokojenie wierzycieli należałoby do byłych wspólników (akcjonariuszy). Taki pogląd może uzasadniać omawiany już wcześniej wyrok Sądu Najwyższego z 13 grudnia 2006 r. (II CSK 300/06). Skoro w przedstawionym stanie faktycznym możliwe było wyjątkowo pozwanie członków zarządu, bez uzyskania tytułu wykonawczego względem spółki, to analogicznie możliwe byłoby zaspokojenie wierzycieli przez samych wspólników (akcjonariuszy). W drugim wariancie pełnomocnik do spraw likwidacji powoływany byłby przez samych wspólników (akcjonariuszy). W trzecim przypadku natomiast pełnomocnika powoływałby sąd rejestrowy. Uważam, że ustanowienie pełnomocnika zapewniałoby zabezpieczenie interesów wierzycieli w szerszym stopniu niż w sytuacji, gdyby mieliby tego dokonać sami wspólnicy (akcjonariusze). Kwestia ta, czyli samo ustanowienie pełnomocnika i wybór podmiotu, który jest za ten fakt odpowiedzialny, jest jednak kwestią wtórną i techniczną. Nie przeczy to proponowanej przeze mnie koncepcji, ażeby majątek ujawniony po zakończeniu likwidacji przechodził ex lege na wspólników (akcjonariuszy), jako że w obrocie prawnym, po wykreśleniu spółki z rejestru, nie ma już żadnego innego podmiotu, który mógłby być właścicielem tego mienia. Ustanowienie pełnomocnika do spraw likwidacji zapewniałoby jednakże szerszą ochronę niezaspokojonych interesów wierzycieli, które zostały ujawnione we właściwym postępowaniu likwidacyjnym. Instytucja ta służyłaby do właściwego rozporządzenia ujawnionym mieniem. 
6. POGLĄD DRUGI - KWESTIA DOPUSZCZALNOŚCI INGERENCJI ORGANU WŁADZY PUBLICZNEJ W KREOWANIE STOSUNKU SPÓŁKI POPRZEZ WZNOWIENIE POSTĘPOWANIA LIKWIDACYJNEGO

Wznowienie postępowania likwidacyjnego przez organ sądu rejestrowego przeczy także koncepcji umowy spółki jako kreującej stosunek spółki. Wedle art. 163 k.s.h. elementem konstytutywnym powstania spółki z ograniczoną odpowiedzialnością jest między innymi zawarcie umowy spółki i dokonanie wpisu do rejestru. Wymogiem powstania spółki akcyjnej jest natomiast między innymi zawiązanie spółki, w tym podpisanie statutu przez założycieli oraz dokonanie wpisu do rejestru. Kodeks spółek handlowych wymienia więc expressis verbis zawarcie umowy spółki jako element konieczny (choć sam przez się niewystarczający) do powstania podmiotu, jakim jest spółka. W przypadku dokonania wpisu do rejestru przedsiębiorców o wykreśleniu spółki z ograniczoną odpowiedzialnością bądź spółki akcyjnej z rejestru, sąd rejestrowy kształtuje na nowo sytuację prawną, co prowadzi do usunięcia spółki handlowej z obrotu prawnego i traktowania jej jako nieistniejącej. Wpis o wykreśleniu podmiotu z rejestru przedsiębiorców niewątpliwie ma charakter konstytutywny ${ }^{27}$, co oznacza, że przepisy prawa materialnego łączą skutek powstania, jak i ustania bytu prawnego podmiotu wpisanego do rejestru $\mathrm{z}$ chwilą, w której dokonywany jest wpis albo wykreślenie z rejestru. Potwierdzeniem takiego charakteru wpisu jest chociażby treść przepisu art. 272 k.s.h., zgodnie z którym rozwiązanie spółki z ograniczoną odpowiedzialnością następuje po przeprowadzeniu likwidacji, z chwilą wykreślenia spółki z rejestru. Podsumowując - dokonanie w rejestrze wpisu, który ma charakter konstytutywny. Wznowienie postępowania likwidacyjnego przez organ rejestrowy przeczy koncepcji, że spółka kapitałowa powstaje między innymi przez zawarcie umowy między wspólnikami (akcjonariuszami). Postępowanie likwidacyjne nie może bowiem toczyć się przeciwko podmiotowi, który został rozwiązany (nie istnieje). Organ rejestrowy ingeruje bowiem w stan prawny w ten sposób, że przez wznowienie postępowania likwidacyjnego

27 A. Michnik, Postępowanie o wpis do rejestru przedsiębiorców, Warszawa 2009, s. $287 \mathrm{i} \mathrm{n.}$ 
„reaktywuje” niejako spółkę z ograniczoną odpowiedzialnością bądź spółkę akcyjną. Czyni to niewątpliwie bez woli byłych wspólników (akcjonariuszy), którzy przez decyzję organu rejestrowego o wznowieniu postępowania rejestrowego są zmuszeni ponownie wstąpić w role wspólników (akcjonariuszy). Jest to niewątpliwe naruszenie zasady pewności obrotu, bowiem po zakończeniu postępowania likwidacyjnego były wspólnik (akcjonariusz) ma prawo być przeświadczony, że spółka na dobre została usunięta z obrotu i nie łączy go z nią więź korporacyjna, z której wynikają nie tylko uprawnienia wspólnika (akcjonariusza), lecz także obowiązki.

\section{Pogląd TRZECI - W ODNIESIENIU DO REGULACJI DOTYCZĄCYCH KSIĄG WIECZYSTYCH}

Jak już wskazano, problematyczną kwestię stanowi sytuacja, gdy mamy do czynienia $\mathrm{z}$ majątkiem spółki, w którego skład wchodzi nieruchomość. W księdze wieczystej, po zakończeniu postępowania likwidacyjnego wobec spółki, widnieje wpis, że właścicielem nieruchomości jest podmiot, który już nie istnieje, bowiem został w wyniku postępowania likwidacyjnego wykreślony z rejestru przedsiębiorców. Przyjęcie koncepcji, że ujawniony majątek przechodzi ex lege na byłych wspólników (akcjonariuszy), wymagałby zmian w ustawodawstwie dotyczącym ksiąg wieczystych poprzez uwzględnienie przekształceń własnościowych nieruchomości. W mojej ocenie należałoby wprowadzić regulację umożliwiającą modyfikację wpisu na wniosek byłych wspólników (akcjonariuszy), którzy udowodnią, że jako osoby, które łączyła ze spółką więź korporacyjna, mają uprawnienie rzeczowe lub obligacyjne do ujawnionego składnika mienia. Odpowiednim trybem ku temu byłoby postępowanie nieprocesowe przeprowadzane przed sądem powszechnym. W tak istotnej kwestii, jak ustalenie prawa własności nieruchomości, w mojej ocenie, konieczna byłaby ingerencja organu sądowego, który byłby w stanie przeprowadzić kompleksowe postępowanie dowodowe. Orzeczenie sądu wydane w takim postępowaniu byłoby podstawą modyfikacji wpisu w księdze wieczystej po złożeniu wniosku do wydziału wieczystoksięgowego. Orzeczenie takie miałoby charakter konstytutywny, bowiem ingerowałoby w stosunki prawne 
regulujące prawo własności nieruchomości. Takie postępowanie należałoby przeprowadzić także w przypadku ujawnienia się po przeprowadzeniu postępowania likwidacyjnego majątku w postaci rzeczy ruchomej. Kolejną problematyczną kwestią jest sytuacja, w której byli wspólnicy (akcjonariusze) nie mogliby nabyć nieruchomości (np. w przypadku nieruchomości rolnej) albo nie otrzymaliby zgody na jej nabycie (w przypadku nabycia nieruchomości przez cudzoziemców zezwolenie jest wydawane, w drodze decyzji administracyjnej, przez ministra właściwego do spraw wewnętrznych, jeżeli sprzeciwu nie wniesie Minister Obrony Narodowej, a w przypadku nieruchomości rolnych, jeżeli sprzeciwu również nie wniesie minister właściwy do spraw rozwoju wsi) ${ }^{28}$. W takim wypadku dokonanie omawianego wpisu w księdze wieczystej byłoby działaniem contra legem. Jako że w obecnym stanie prawnym nieruchomość nie może nie mieć właściciela, należałoby w przypadku braku zgody w postaci decyzji administracyjnej lub wniesienia sprzeciwu przez Ministra Obrony Narodowej lub ministra właściwego do spraw rozwoju wsi rozważyć ustanowienie właścicielem Skarbu Państwa i ustanowienie odpowiedniego odszkodowania na rzecz byłych wspólników (akcjonariuszy).

Kolejnym zagadnieniem jest płynność składu wspólników (akcjonariuszy). O ile skład wspólników spółki z ograniczoną odpowiedzialnością zmienia się rzadziej niż w przypadku spółki akcyjnej, o tyle w przypadku spółki akcyjnej skład akcjonariatu może być elastyczny. W tym przypadku należałoby się zastanowić, kogo wpisać jako właściciela nieruchomości w księdze wieczystej. Należałoby przyjąć, że byliby to wspólnicy (akcjonariusze) w składzie bezpośrednio przed przeprowadzeniem postępowania likwidacyjnego spółki.

Należy odnieść się także do sytuacji, w której ujawnione składniki majątku nieistniejącej już spółki zostały zbyte po przeprowadzeniu postępowania likwidacyjnego. Kwestię tę należy rozpatrywać, powołując się na zasadę jawności ksiąg wieczystych. Jeżeli podmiot zbywający działał w złej wierze, a należy ją przypisać temu podmiotowi, gdy w księdze

28 Ustawa z 24 marca 1920 r. o nabywaniu nieruchomości przez cudzoziemców (tekst jedn.: Dz. U. z 2017 r. poz. 2278). 
wieczystej jako właściciel widniała nieistniejąca już spółka, czynność taką należałoby uznać za bezskuteczną. Bardziej problematyczną kwestię stanowi zbycie rzeczy ruchomej. W takim przypadku należałoby brać pod uwagę jedynie dobrą wiarę podmiotu zbywającego ruchomość.

\section{Podsumowanie}

Zaprezentowane przeze mnie poglądy doktryny i orzecznictwa nie są spójne i problematyka ujawnienia majątku spółki po zakończeniu postępowania likwidacyjnego w mojej ocenie wymaga ingerencji ustawodawcy. Ingerencja ta musiałaby dotyczyć nie tylko regulacji, jaką jest kodeks spółek handlowych, lecz także regulacji dotyczących ksiąg wieczystych. W aktualnym stanie prawnym, moim zdaniem, należałoby wysunąć pewne propozycje de lege ferenda, które pozwoliłyby znormalizować obecną, niejasną (także w orzecznictwie Sądu Najwyższego) sytuację. Należałoby się zastanowić, czy właściwym rozwiązaniem nie byłoby powrócenie do koncepcji, którą zaprezentował Sąd Najwyższy w orzeczeniu z 26 maja 1936 r. (II C 331/36), a mianowicie przyznanie ex lege majątku spółki ujawnionego po zakończonym postępowaniu likwidacyjnym - byłym wspólnikom (akcjonariuszom). Instytucją zapewniającą ochronę wierzycieli - jednakże tylko tych, których roszczenia zostały ujawnione we właściwym postępowaniu likwidacyjnym, byłoby powołanie instytucji pełnomocnika do spraw likwidacji. Jego zadaniem byłoby rozdysponowanie ujawnionym majątkiem w ten sposób, by uczynić zadość słusznym interesom wierzycieli. Byłoby to postępowanie o charakterze quasi-likwidacyjnym, nienaruszającym bowiem zasady, że majątek ujawniony po zakończeniu postępowania przypada ex lege byłym wspólnikom (akcjonariuszom). W przypadku gdy wszyscy zgłoszeni wierzyciele zostali zaspokojeni w pierwotnym postępowaniu likwidacyjnym, przeprowadzenie postępowania quasi-likwidacyjnego byłoby zbędne. Prezentowane przeze mnie rozwiązanie nie naruszałoby zasady, że powołanie spółki jest wyrazem woli wspólników (akcjonariuszy), mającej odzwierciedlenie w umowie spółki. Należy przy tym odrzucić zasadność stosowania per analogiam przepisów dotyczących likwidacji spółki w organizacji, bowiem sytuacja ujawnienia majątku spółki po zakończeniu postępowania likwidacyjnego różni się w sposób 
zasadniczy od sytuacji, gdy likwidowana jest spółka w fazie organizacji. W przypadku ujawnienia się majątku spółki w postaci ruchomości lub nieruchomości konieczne byłoby przeprowadzenie dodatkowego postępowania sądowego, które pozwoliłoby ustalić status prawny składnika majątku nieistniejącej już spółki. W postępowaniu sądowym należałoby rozstrzygnąć także kwestię, kto jest odpowiedzialny za przeoczenie składnika majątku spółki. Podmiot ten byłby zobowiązany do pokrycia kosztów wynikłych z niepełnego przeprowadzenia pierwotnego postępowania likwidacyjnego.

\section{PROBLEMATYKA MAJĄTKU UJAWNIONEGO PO ZAKOŃCZENIU POSTĘPOWANIA LIKWIDACYJNEGO SPÓ£KI KAPITAŁOWEJ}

\section{Streszczenie}

Tematyka artykułu skupia się na problemie majątku polikwidacyjnego spółki kapitałowej. Sąd Najwyższy stanął na stanowisku, że dopuszczalne jest wznowienie postępowania likwidacyjnego w stosunku do spółki, która została wykreślona z rejestru. Zgodnie z orzecznictwem Sądu Najwyższego spółka taka ma zdolność likwidacyjną i sądową. W artykule zostaną przedstawione argumenty przeciwko stanowisku wyrażonemu w orzecznictwie Sądu Najwyższego dotyczącego statusu majątku polikwidacyjnego spółki i niezbędnych postępowań sądowych.

\section{Company Assets Disclosed after Liquidation}

\section{Summary}

This article concerns the assets a company still has after it has been liquidated. The position adopted by the Polish Supreme Court is that a new liquidation procedure may be instituted for a company which has been removed from the register of companies. According to the Supreme Court such a company may be liquidated again and may take part in court proceedings. The article presents arguments against the Supreme Court's position on the assets of a company which has been liquidated, 
and offers proposals for new legislation on the legal status of a company's assets following liquidation and the necessary court proceedings.

Słowa kluczowe: spółki kapitałowe; majątek polikwidacyjny spółki kapitałowej; postępowanie likwidacyjne spółki kapitałowej.

Keywords: companies; company assets following liquidation; liquidation procedure.

\section{Literatura:}

Babiarz S., Łukowski W., Glosa do uchwaly SN z dnia 24 stycznia 2007 r., III CZP 143/06, «Prawo Spółek» 3/2010, s. 52-58.

JA U ВеCKi A., Glosa do uchwaty SN z dnia 24 stycznia 2007 r., III CZP 143/06, «OSP» 7/2008, s. 74-80.

Koniewicz A., Majątek polikwidacyjny osób prawnych na przykładzie spółek kapitałowych, Warszawa 2010.

Koniewicz A., Glosa do uchwały SN z dnia 24 stycznia 2007 r., III CZP 143/06, «Glosa» 4/2010, s. 40-46.

Kos R., Porzycki M., Sytuacja prawna majątku pozostałego po wykreśleniu spótki kapitałowej - uwagi na gruncie postulatu przymusowej likwidacji niewypłacalnych spółek, «Monitor Prawa Handlowego» 3/2013, s. 23-30.

Michalski M., Spółka akcyjna, red. A. Kidyвa, Warszawa 2014.

Michniк A., Postępowanie o wpis do rejestru przedsiębiorców, Warszawa 2009. Potrzeszcz R., Wykreślenie spótki kapitałowej bez (właściwej) likwidacji - ze stanowiska wierzycieli, «Rejent» 8.5/1998, s. 142-168.

NAwORski J.P., Kodeks spółek handlowych. Komentarz, red. T. SiemiąTKоwsKi, R. Potrzeszcz, Warszawa 2011.

Scнміdт K., Gesellschaftsrecht, Köln-Berlin-Bonn-München 2002.

Witosz A., Rozwiązanie i likwidacja spółek handlowych, Warszawa 2014.

Wolbach Ł., Likwidacja spółki kapitałowej. Prawo, podatki, rachunkowość, red. W. Missala, Warszawa 2012.

Wowerka A., Glosa do uchwaty SN z dnia 24 stycznia 2007 r., III CZP 143/06, «Gdańskie Studia Prawnicze - Przegląd Orzecznictwa» 3/2008, s. 57-66. 